\title{
Inheritance of Anthracnose Resistance in Common Bean Differential Cultivar AB 136
}

\author{
Ana Lilia Alzate-Marin and Gilson Soares Baía, BIOAGRO; Trazilbo José de Paula Júnior, \\ EPAMIG/BIOAGRO; Geraldo Assis de Carvalho, BIOAGRO; Everaldo Gonçalves de Barros, Dept. de \\ Biologia Geral/BIOAGRO; and Maurilio Alves Moreira, Dept. de Bioquímica e Biologia Molecular/BIOAGRO, \\ Universidade Federal de Viçosa, 36571-000 Viçosa, MG, Brasil
}

\begin{abstract}
Alzate-Marin, A. L., Baía, G. S., de Paula Júnior, T. J., de Carvalho, G. A., de Barros, E. G., and Moreira, M. A. 1997. Inheritance of anthracnose resistance in common bean differential cultivar AB 136. Plant Dis. 81:996-998.

Inheritance of anthracnose resistance of the common bean (Phaseolus vulgaris L.) differential cultivar $\mathrm{AB} 136$ to races 89, 64, and 73 (binary system designation) was studied in crosses with the susceptible differential cultivars Michelite (race 89), Mexico 222 (race 64), and Cornell 49242 (race 73). In each cross two progenitors, the $F_{1}, F_{2}$, and backcross-derived plants were inoculated with the respective race under environmentally controlled greenhouse conditions. The results indicate that single dominant gene(s) control resistance to races 89 and 64, giving a segregation ratio of $3: 1$ in the $F_{2}, 1: 0$ in the backcrosses to $A B$ 136, and 1:1 in the backcross to Michelite (race 89), and to Mexico 222 (race 64). For race 73, the following segregation ratios between resistant and susceptible plants were observed: 13:3 in the $F_{2}, 1: 0$ in the backcross to $\mathrm{AB}$ 136, and 1:1 in the backcross to Cornell 49-242. Such results suggest that two independent genes may determine resistance of $\mathrm{AB} 136$ to race 73, one dominant $(\mathrm{Co}-6)$ and one recessive that is proposed to be assigned $\mathrm{co}-8$. Genotypes $\mathrm{Co}_{-} 6_{-}$or $\mathrm{co}-8 \mathrm{co}-8$ would condition resistance, whereas susceptibility would be present in genotypes co-6 co-6 $\mathrm{Co}-8_{-}$. Given the dominant nature of anthracnose resistance genes present in line $\mathrm{AB} 136$ and its resistance to 25 races of Colletotrichum lindemuthianum identified in Brazil by other researchers, we included this cultivar as one of the donor parents in our molecular marker-assisted backcross breeding program, to develop common bean cultivars resistant to anthracnose and adapted to Central Brazil.
\end{abstract}

Anthracnose, caused by the fungus Colletotrichum lindemuthianum (Sacc. \& Magnus) Lams.-Scrib., is one of the most destructive diseases affecting common bean (Phaseolus vulgaris L.) in tropical and subtropical areas of Latin America and Central and Eastern Africa (7). In such areas a complete yield loss can occur with susceptible cultivars when contaminated seeds are used and the environmental conditions are favorable for the pathogen development (12).

In susceptible cultivars anthracnose symptoms can appear on any plant part. Initial symptoms may appear on cotyledonary leaves as small, dark brown to black lesions. Hypocotyl-infected tissues manifest minute rust-colored specks. The specks gradually enlarge longitudinally and form sunken lesions or eye-spots. These enlarge on hypocotyl of the young seedling, causing it to rot off. On older stems, the eye-shaped lesion is about 5 to $7 \mathrm{~mm}$ in length. In the leaves, lesions appears first on

Corresponding author: Maurilio Alves Moreira E-mail: moreira@mail.ufv.br

Accepted for publication 17 May 1997.

Publication no. D-1997-0625-01R

(C) 1997 The American Phytopathological Society the lower surface and leaf veins as small, angular, brick-red to purple spots which become dark brown to black. Later, lesions also appear on veinlets on the upper surface of leaves (3).

Pod infections appear as flesh to rust-colored lesions. The lesions develop into sunken cankers (1 to $10 \mathrm{~mm}$ in diameter) which are delimited by a slightly raised black ring and surrounded by a reddish brown border (9). The fungus can invade the pod, and the mycelia and conidia infect the cotyledons or seed coat of developing seeds. Infected seeds are often discolored and may contain dark brown to black cankers $(3,7)$.

The use of resistant cultivars is considered to be the most viable option for controlling anthracnose, particularly for smallscale growers $(15,17)$. However, the existence of many physiological races of the pathogen in regions such as Southern and Central Brazil represents an obstacle for creating new common bean cultivars resistant to anthracnose. Knowledge about the frequency and distribution of physiological races of the pathogen, combined with the use of different resistance genes, are needed to develop more stable resistant cultivars adapted to such regions of Brazil (13).

A number of common bean lines have been evaluated for resistance to many races of anthracnose at the Centro Internacional de Agricultura Tropical (CIAT, Cali, Colombia). Among them, line AB 136, selected as one of the 12 international differential cultivars for anthracnose, is one of the most resistant (8). In addition, it has been demonstrated that line $\mathrm{AB} 136$ showed resistance to 25 races of $C$. lindemuthianum collected in several common bean growing regions in Brazil (13). The purpose of this work was to define the inheritance pattern of resistance present in the AB 136 line in segregating populations derived from crosses made with the susceptible cultivars Michelite, Mexico 222, and Cornell 49-242 to pathogen races collected in the states of Minas Gerais and Espirito Santo (Central Brazil).

\section{MATERIALS AND METHODS}

Isolates. Three isolates of $C$. lindemuthianum belonging to three different races $(64,73$, and 89$)$ used in this work are defined in Table 1 and are among the 25 races previously characterized by Rava et al. (13). The original cultures were provided by Carlos Rava and Aloisio Sartorato (Centro Nacional de Pesquisa de Arroz e Feijão/Empresa Brasileira de Pesquisa Agropecuaria [CNPAF/EMBRAPA], Goiânia, GO, Brazil). To obtain high sporulation levels, fungi were grown in sterilized young pods of common bean for approximately 10 days. In order to confirm their phenotypes, isolates were inoculated in the 12 international common bean differential cultivars for anthracnose (8).

Genetic materials and crosses. Seeds of the differential cultivars Michelite, Cornell 49-242, Mexico 222, and AB 136
Table 1. Origin of isolates of Colletotrichum lindemuthianum ${ }^{\mathrm{a}}$ used in experiments

\begin{tabular}{lcc}
\hline $\begin{array}{l}\text { Race } \\
\text { (binary system) }\end{array}$ & $\begin{array}{c}\text { Group/race } \\
\text { (classical nomenclature) }\end{array}$ & $\begin{array}{c}\text { Origin } \\
\text { (state - country) }\end{array}$ \\
\hline 64 & Mexican I/ Mexican I & Espirito Santo, Brazil \\
73 & Alpha/Alpha BR & Espirito Santo, Brazil \\
89 & Alpha/Alpha BR & Minas Gerais, Brazil \\
\hline
\end{tabular}

(1)


were provided by CNPAF/EMBRAPA. Some of their traits are shown in Table 2. Line AB 136 (male progenitor) was crossed with each of the other three cultivars. Part of the $F_{1}$ seeds was planted and the $F_{1}$ plants were backcrossed to $\mathrm{AB} 136$ $\left(\mathrm{BC}_{\mathrm{r}}\right)$ and to the corresponding susceptible progenitor $\left(\mathrm{BC}_{\mathrm{s}}\right)$. The remaining $\mathrm{F}_{1}$ seeds were selfed to generate $F_{2}$ seeds. All crosses were performed in the greenhouse.

Genetic analysis of $\mathrm{AB} 136$ resistance to anthracnose. Spores from races 89,64 , and 73 were inoculated in plants derived from the following crosses: Michelite $\times$ $\mathrm{AB}$ 136, Mexico $222 \times \mathrm{AB}$ 136, and Cornell $\times$ AB 136, respectively (Table 2 ). For each cross, the following number of seeds were sowed in the greenhouse in a completely randomized design: 30 seeds from each progenitor, $30 \mathrm{~F}_{1}$ seeds, $195 \mathrm{~F}_{2}$ seeds, and 60 seeds from each backcross $\left(\mathrm{BC}_{\mathrm{r}}\right.$ and $\left.\mathrm{BC}_{\mathrm{s}}\right)$. Fourteen days after sowing, the first expanded trifoliate leaf from each of the 405 plants was inoculated on the lower and upper leaf surfaces with spore suspensions of $C$. lindemuthianum $(1.2 \times$ $10^{6}$ spores $/ \mathrm{ml}$ ). Spore suspensions were applied with a horsehair paint brush. The plants were then incubated for 7 days in a humidity chamber, which was maintained at 20 to $22^{\circ} \mathrm{C}$ and $100 \%$ relative humidity.

After this period, each plant was scored visually for the disease symptoms using a 1 to 9 scale adapted from Pastor-Corrales (8) where 1 = plants with no visible symptoms; 2 = few isolated small lesions on mid-veins in the lower leaf surface; $3=$ more frequency of small lesions on midveins in the lower leaf surface; $4=$ lesions present in the mid-vein and occasionally in secondary leaf veins; 5 = many small lesions scattered on mid- and secondary veins; $6=$ many small lesions as described in grade 5 in the lower and upper leaf surface and in the stems and petioles; $7=$ large lesions scattered over the leaf blade and many lesions in the stems and petioles; $8=$ many large coalesced lesions accompanied by tissue breakdown and chlorotic or abscised leaflets, reduced plant growth, and many lesions in stems and petioles; and $9=$ severely diseased or dead plants.

Resistant ( $\mathrm{R}$ ) phenotype was assigned to plants with no or limited symptoms (scores 1 to 3); whereas plants graded 4 or greater were considered to be susceptible (S). The class frequencies obtained were tested for goodness-of-fit to theoretical ratios with chi-square tests.

\section{RESULTS AND DISCUSSION}

Results of inoculations confirmed that cultivar $\mathrm{AB} 136$ is resistant to $C$. lindemuthianum races 89 (Table 3), 64 (Table 4), and 73 (Table 5) under greenhouse conditions. In contrast, cultivars Michelite, Mexico 222, and Cornell 49-242 are susceptible to races 89,64 , and 73 , respectively, under the same conditions. Similar results have been reported which demon- strated that line $\mathrm{AB} 136$ showed incompatible reaction when inoculated with 25 races of $C$. lindemuthianum detected in Brazil (13).

Observed and expected frequencies for resistant and susceptible reactions to race 89, for the progenitors AB 136, Michelite, and the populations derived from crosses between them, are shown in Table 3. Chisquare values revealed that a good fit was obtained for the segregation ratio of $3: 1$ in the $F_{2}, 1: 1$ when the $F_{1}$ was backcrossed to Michelite, and 1:0 when the $F_{1}$ was backcrossed to $A B$ 136. Similar results were observed for the cross between $\mathrm{AB} 136$ and Mexico 222 inoculated with race 64 (Table 4). The segregation ratios of 3:1 in the $F_{2}$ and the good fit to the expected ratios in the backcross generations (Tables
3 and 4) indicate that resistance of $\mathrm{AB} 136$ to races 89 and 64 is controlled by a single dominant gene. From these data it cannot be determined if these genes are independent or if they are in fact the same gene. However, preliminary results from our laboratory show that these two putative genes are tagged by the same PCR-based molecular marker, indicating that resistance to these two races in AB 136 is conditioned by one single dominant gene (data not shown). Most likely, this gene is the same reported previously (18) and assigned as $\mathrm{Co}-6$.

Table 5 gives the observed and expected frequencies for resistant and susceptible reactions to race 73 for progenitors $\mathrm{AB} 136$ and Cornell 49-242, the $F_{1}$ and $F_{2}$, the $F_{1}$ backcrossed to Cornell 49-242, and the $F_{1}$

Table 2. Characteristics and type of reactions to isolates of Colletotrichum lindemuthianum of the progenitors Michelite, Mexico 222, Cornell 49-242, and AB 136

\begin{tabular}{|c|c|c|c|c|c|}
\hline Progenitor & Growth habit & Seed size & Seed color & Race & $\begin{array}{l}\text { Reaction to } \\
\text { anthracnose }\end{array}$ \\
\hline Michelite & $\begin{array}{r}\text { Indeterminate } \\
\text { weak-stemmed }\end{array}$ & Small & White & Meso American & $\begin{array}{r}\text { Susceptible to } \\
\text { race } 89\end{array}$ \\
\hline Mexico 222 & $\begin{array}{r}\text { Determinate } \\
\text { erect bush }\end{array}$ & Medium & White & Durango & $\begin{array}{r}\text { Susceptible to } \\
\text { race } 64\end{array}$ \\
\hline Cornell 49-242 & $\begin{array}{l}\text { Indeterminate } \\
\text { weak-stemmed }\end{array}$ & Small & Black & Meso American & $\begin{array}{r}\text { Susceptible to } \\
\text { race } 73\end{array}$ \\
\hline AB 136 & Indeterminate & Small & Red & Meso American & $\begin{array}{r}\text { Resistant to all } \\
\text { three races }\end{array}$ \\
\hline
\end{tabular}

Table 3. Segregation for resistance to race 89 of Colletotrichum lindemuthianum in the cross Michelite $\times$ AB 136

\begin{tabular}{lcccccc}
\hline & & \multicolumn{2}{c}{ No. of plants } & Expected & & \\
\cline { 3 - 4 } Pedigree & Generation & Resistant & Susceptible & ratio & $\chi^{\mathbf{2}}$ & $\boldsymbol{P}$ \\
\hline Michelite & $\mathrm{P} 1$ & 0 & 27 & $\ldots$ & $\ldots$ & $\ldots$ \\
$\mathrm{AB} 136$ & $\mathrm{P} 2$ & 30 & 0 & $\ldots$ & $\ldots$ & $\ldots$ \\
Michelite $\times \mathrm{AB} 136$ & $\mathrm{~F}_{1}$ & 17 & 0 & $\ldots$ & $\ldots$ & $\ldots$ \\
Michelite $\times \mathrm{AB} \mathrm{136}$ & $\mathrm{F}_{2}$ & 129 & 42 & $3: 1$ & 0.031 & 0.9 \\
$\mathrm{~F}_{1} \times$ Michelite & $\mathrm{BC}_{\mathrm{s}}$ & 29 & 30 & $1: 1$ & 0.017 & 0.9 \\
$\mathrm{~F}_{1} \times \mathrm{AB} 136$ & $\mathrm{BC}_{\mathrm{r}}$ & 56 & 0 & $1: 0$ & 0.000 & 1.0 \\
\hline
\end{tabular}

Table 4. Segregation for resistance to race 64 of Colletotrichum lindemuthianum in the cross Mexico $222 \times$ AB 136

\begin{tabular}{lcccccc}
\hline & & \multicolumn{2}{c}{ No. of plants } & Expected & & \\
\cline { 3 - 4 } Pedigree & Generation & Resistant & Susceptible & ratio & $\chi^{\mathbf{2}}$ & $\boldsymbol{P}$ \\
\hline Mexico 222 & $\mathrm{P} 1$ & 0 & 30 & $\ldots$ & $\ldots$ & $\ldots$ \\
$\mathrm{AB} 136$ & $\mathrm{P} 2$ & 30 & 0 & $\ldots$ & $\ldots$ & $\ldots$ \\
Mexico 222 $\times$ AB 136 & $\mathrm{F}_{1}$ & 22 & 0 & $\ldots$ & $\ldots$ & $\ldots$ \\
Mexico 222 $\times$ AB 136 & $\mathrm{F}_{2}$ & 145 & 45 & $3: 1$ & 0.175 & 0.7 \\
$\mathrm{~F}_{1} \times$ Mexico 222 & $\mathrm{BC}_{\mathrm{s}}$ & 28 & 31 & $1: 1$ & 0.152 & 0.7 \\
$\mathrm{~F}_{1} \times$ AB 136 & $\mathrm{BC}_{\mathrm{r}}$ & 56 & 0 & $1: 0$ & 0.000 & 1.0 \\
\hline
\end{tabular}

Table 5. Segregation for resistance to race 73 of Colletotrichum lindemuthianum in the cross Cornell $49-242 \times$ AB 136

\begin{tabular}{lcccccc}
\hline & & \multicolumn{2}{c}{ No. of plants } & Expected & & \\
\cline { 3 - 6 } Pedigree & Generation & Resistant & Susceptible & ratio & $\chi^{\mathbf{2}}$ & $\boldsymbol{P}$ \\
\hline Cornell 49-242 & $\mathrm{P} 1$ & 0 & 30 & $\ldots$ & $\ldots$ & $\ldots$ \\
AB 136 & $\mathrm{P} 2$ & 27 & 0 & $\ldots$ & $\ldots$ & $\ldots$ \\
Cornell 49-242 $\times \mathrm{AB} \mathrm{136}$ & $\mathrm{F}_{1}$ & 22 & 0 & $\ldots$ & $\ldots$ & $\ldots$ \\
Cornell 49-242 $\times$ AB 136 & $\mathrm{F}_{2}$ & 155 & 35 & $13: 3$ & 0.013 & 0.9 \\
$\mathrm{~F}_{1} \times$ Cornell 49-242 & $\mathrm{BC}_{\mathrm{s}}$ & 27 & 31 & $1: 1$ & 0.275 & 0.7 \\
$\mathrm{~F}_{1} \times$ AB 136 & $\mathrm{BC}_{\mathrm{r}}$ & 58 & 0 & $1: 0$ & 0.000 & 1.0 \\
\hline
\end{tabular}


backcrossed to $\mathrm{AB}$ 136. Chi-square values revealed that a good fit was obtained for the segregation ratio of 13:3 in the $F_{2}, 1: 1$ when the $F_{1}$ was backcrossed to Cornell 49-242, and 1:0 when the $F_{1}$ was backcrossed to $A B$ 136. Such results suggest the action of two independent genes for resistance of $\mathrm{AB} 136$ to pathogen race 73 : one dominant (Co-6) (18) and one recessive, which is proposed to be assigned the genetic symbol $\mathrm{Co}-8$. Genotypes $\mathrm{Co}-6_{-}$or $\mathrm{co}-8 \mathrm{co}-8$ would condition resistance, whereas susceptibility would be present in genotypes $\mathrm{co}-6 \mathrm{co}-6 \mathrm{Co}-8_{-}$.

Anthracnose resistance in common bean has been reported to be controlled by a single dominant gene $(1,5)$. However, it has been demonstrated that two independent dominant genes are responsible for resistance of cultivar G 2333 (10). A third independent dominant gene (Mexique 3) has also been assigned to condition resistance of cultivar G 2333 (18). In addition, the presence of more then one gene pair in complex interactions has also been observed. For instance, it has been reported that resistance to races alpha, gamma, and delta are conditioned by two recessive genes, and for race beta one recessive gene (14). Besides, resistance to race beta has been assigned to complementarity of dominant or recessive genes (2), and yet by a multiple allelic series of a recessive gene (6). Resistance to race BA-5 (Brazil group I) has been shown to be conditioned by the action of a dominant and a duplicated recessive gene (11).

Using the cross Michelite $\times \mathrm{AB} 136$, it was concluded that single dominant genes in $\mathrm{AB} 136$ are responsible for resistance to races alpha and delta and that the action of a dominant and complementary genes are responsible for resistance to race kappa (16). A single dominant gene present in the cultivar Catrachita, a breeding line derived from the cross BAT $1225 \times \mathrm{AB} 136$, has been shown to be responsible for resistance to races 7 and 23 (delta), 64 (alpha), and 73 (alpha-Brazil) $(4,18)$.

The data presented in this work and that of others $(16,18)$ confirm that at least one single dominant gene in cultivar AB 136 is conditioning resistance to races delta, alpha, alpha-Brazil, kappa, and Mexican I.

On the other hand, this is the first observation of a second gene (in this case, recessive) conditioning resistance in cultivar $\mathrm{AB}$
136 to anthracnose race 73 (alpha-Brazil). This gene has not been observed in cultivar Catrachita, an improved line derived from AB 136, probably because it has not been transmitted during the breeding process, or else in view of not using the susceptible cultivar Cornell 49-242 (18). Also, this gene has not been previously detected in cultivar $\mathrm{AB}$ 136, most likely because race 73 (alpha-Brazil) was not used in that study (16). Based on these data and on that of others $(10,17)$, it was concluded that the genetic basis for inheritance of anthracnose resistance in common bean appears to be dependent, on the tester genotype used as the susceptible parent, and on the pathogen physiological race used for inoculation.

Given the dominant nature of anthracnose resistance gene(s) present in the $\mathrm{AB}$ 136 cultivar observed in this study against important pathogen physiological races that occur in Brazil, and the broad spectrum of resistance present in this cultivar (13), we selected it as one of the donor parents in our molecular marker-assisted backcross breeding program, to create common bean cultivars resistant to anthracnose and adapted to Central Brazil.

\section{ACKNOWLEDGMENTS}

This work was supported by grant no. 64.93.0430.00 from PADCT/FINEP and no. 854/92 from FAPEMIG. A. L. Alzate-Marin was supported by a fellowship from CAPES/MEC; G. S. Baía and G. A. Carvalho were supported by fellowships from RHAE/MCT/CNPq. We thank Prof. Laercio Zambolim for his technical assistance during the conduction of this work.

\section{LITERATURE CITED}

1. Bannerot, H., Deieux, M., and Fouilloux, G. 1971. Mise en evidence d'un second de resistance totale a l'anthracnose chez le haricot. Ann. Amelior. Plant. (Paris) 21:83-85.

2. Cárdenas, R., Adams, M. W., and Andersen, A. 1964. The genetic system for reaction of field beans (Phaseolus vulgaris L.) to infection by three physiologic races of Colletotrichum lindemuthianum. Euphytica 13(2): 178-186.

3. Chaves, G. 1980. La antracnosis. Pages 37-53 in: Problemas de Producción del Frijol. H. Schwartz, \& Galvez, eds. Centro Internacional de Agricultura Tropical, Cali, Colombia.

4. Kelly, J. D., Afanador, L., and Cameron L. S. 1994. New races of Colletotrichum lindemuthianum in Michigan and implications in dry bean resistance breeding. Plant Dis. 78(9):892-894.

5. Mastenbrok, C. 1960. A breeding programme for resistance in dry shell haricot beans based on a new gene. Euphytica. 9:177-185.
6. Muhalet, C. S., Adams, M. W., Saettler, A W., and Ghaderi, G. 1981. Genetic system for the reaction of field beans to Beta, Gamma and Delta races of Colletotrichum lindemuthianum. J. Am. Soc. Hortic. Sci. 106:601604.

7. Pastor-Corrales, M. 1985. Enfermedades del frijol causadas por hongos. Pages 172-180 in FRIJOL: Investigación y Producción. López, Fernández, \& Schoonhoven, eds. Centro Internacional de Agricultura Tropical, Cali, Colombia.

8. Pastor-Corrales, M. 1992. Recomendaciones y acuerdos del primer taller de antracnosis en América Latina. Pages 240-250 in: La Antracnosis del Frijol Común, Phaseolus vulgaris, en América Latina. Doc. de trabajo 113. Centro Internacional de Agricultura Tropical, Cali, Colombia.

9. Pastor-Corrales, M., and Tu, J. C. 1989. Anthracnose. Pages 77-93 in: Bean Production Problems in the Tropics. Schwartz \& Corrales, eds. Centro Internacional de Agricultura Tropical, Cali, Colombia.

10. Pastor-Corrales, M. A., Erazo, O. A., Estrada, E. I., and Singh, S. P. 1994. Inheritance of anthracnose resistance in common bean accession G 2333. Plant Dis. 78: 959-962.

11. Peloso, M. J. del, Cardoso, A., Vieira, C. Saraiva, L. S., and Zimmerman, M. J. O. 1989. Genetic system for the reaction of Phaseolus vulgaris to the BA-2 (alpha) race of Colletotrichum lindemuthianum. Rev. Bras. Genet. 12:313-318.

12. Peloso, M. J. del. 1992. Antracnose do feijoeiro no Estado de Minas Gerais-Brasil Pages 86-108 in: La antracnosis del Frijol Común, Phaseolus vulgaris, en América Latina. Doc. de trabajo 113. Centro Internacional de Agricultura Tropical, Cali, Colombia.

13. Rava, C., Purchio, A., and Sartorato, A. 1994 Caracterização de patótipos de Colletotrichum lindemuthianum que ocorrem em algumas regiões produtoras de feijoeiro comum. Fitopatol. Bras. 19:167-172.

14. Rudorf, W. 1961. Bean Improvement in Germany. Annu. Rep. Bean Improv. Coop. 4:19

15. Singh, S. P., Pastor-Corrales, M., Molina, A., and Otoya, M. 1992. Breeding common bean for resistance to anthracnose. Pages 198-211 in: La Antracnosis del Frijol Común, Phaseolus vulgaris, en América Latina. Doc. de trabajo 113. Centro Internacional de Agricultura Tropical, Cali, Colombia.

16. Vidigal, C. G. 1994. Herança da resistência às raças Alfa, Delta e Capa de Colletotrichum lindemuthianum (Sacc. et Magn.) Scrib. no feijoeiro (Phaseolus vulgaris L.). Ph.D. thesis. Federal University of Viçosa, Univ. Press, Viçosa, MG, Brazil

17. Vieira, C. 1988. Doenças e Pragas do Feijoeiro. Federal University of Viçosa, Univ. Press, Viçosa, MG, Brazil.

18. Young, R., and Kelly, J. D. 1996. Characterization of the genetic resistance to Colletotrichum lindemuthianum in common bean differential cultivars. Plant Dis. 80:650-654. 